13. Майданик Р. Цивільне право : Загальна частина. Т. I : Вступ у цивільне право. Київ : Алерта, 2012. 472 с.

14.Васильев В.В. Теоретические проблемы детерминизма в системе гражданского права Российской Федерации : монография. Москва : Юнити-Дана ; Закон и право, 2015. $351 \mathrm{c}$.

15. Скакун О. Теорія права і держави : підручник. 2-ге вид. Київ : Алерта ; КНТ ; ЦУЛ, 2010. $520 \mathrm{c.}$

16. Власенко И. Компенсационная функция права (вопросы теории и практики) : автореф. дис. ... канд. юрид. наук. Нижний Новгород, 1995.

17.Байтин М. О принципах и функциях права: новые моменты. Правоведение. 2000. № 3. C. $9-12$.

ХОДИкО Ю. Є., кандидат юридичних наук, доцент кафедри цивільного права № 1 (Національний юридичний університет імені Ярослава Мудрого)

\title{
ЩОДО РОЗУМІННЯ СУТНОСТІ РЕЗУЛЬТАТУ РОБІТ ТА ПОСЛУГ ЯК ОБ'ЄКТІВ ЦИВІЛЬНИХ ПРАВОВІДНОСИН
}

У статті автором розглядається питання сутності результату робіт та послуг як об’єктів цивільних правовідносин. Дослідження сутності вказаних об' єктів надає можливість здійснити формування їх ефективного цивільно-правового режиму.

Вказується, що результат роботи та послуга як об'єкти цивільних правовідносин являють собою результат певної діяльності особи поряд з такими об'єктами, як речі, що створені людиною та результатами інтелектуальної творчої діяльності людини (широке розуміння сутності результату робіт). Сформульований критерій, що дає можливість відмежувати результат робіт як об'єкт цивільних правовідносин від інших схожих за своєю сутністю об'єктів.

Здійснюється співвідношення результату робіт з роботою. Аналізується питання матеріальності та нематеріальності результату діяльності особи, критерії їх визначення. Приділено увагу питанню співвідношення такого результату робіт, який створює річ, змінює іiї властивості, та такого, що втілюється в речі як матеріальному носії (об'єктивується), що має значення для кваліфікації певного результату як об'єкта цивільного правовідношення.

У статті проаналізовано дві найбільш поширені концепції сутності послуги як об'єкта цивільних правовідносин - об'єкта-дії та об'єкта-корисного ефекту. Автором визначено критерії послуги як об'єкта, що сформувалися сьогодні в судовій практиці на основі положень чинного цивільного законодавства та наукових досліджень.

Виділяються особливості результату робіт та послуг як об'єктів цивільних правовідносин, що дають можливість відмежувати вказані об'єкти один від одного. Автором доводиться, що результат робіт та послуга як об'єкти цивіль-

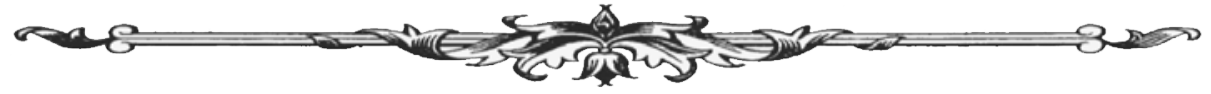


них правовідносин за своєю сутністю є різними об’єктами за формою вираження.

Вирішуються дискусійні питання, що виникають під час визначення сутності результатів робіт та послуг як об'єктів цивільних правовідносин. Проаналізовано українське законодавство, наукові дослідження, актуальна судова практика, зроблені грунтовні висновки, які мають як теоретичне, так і практичне значення щодо окресленого питання.

Ключові слова: об'єкт, об'єкт цииільного правовідношення, об'єкт зобов'язального правовідношення, результат робіт, послуга.

In the article, the author considers the issue of essence of the work product and services as civil matters. The research of the essence of the mentioned objects gives the possibility to conduct the formation of their effective civil law regime.

It is stated that the "work product" and "service" as civil matters represent the result of a person's certain activity along with such objects as things created by a person and the results of intellectual creative activity of a person (wide understanding of the essence of the work product). The criterion is formulated, which makes it possible to separate the work product as a civil matter from other legal objects similar in their essence.

The work product is brought into correlation with the work. The issue of materiality and non-materiality of a person's activity result is analyzed, as well as the criteria for their determination. Attention is paid to the issue of correlation of the work product which creates a thing, changes its properties and one which is embodied in a thing as a material medium (objectified) which is important for treating a certain result as a civil matter.

The article analyzes the two most common concepts of the essence of the service as a civil matter - an object-action and object-useful effect. The author defines the criteria of the service which have been formed in judicial practice today on the basis of provisions of current civil legislation and scientific research.

The peculiarities of the work product and services as civil matters are specified, and they make it possible to distinguish these objects from each other. The author proves that the work product and service as civil matters are essentially distinct objects in the form of their expression.

Disputable issues which arise at determining the essence of work products and services as civil matters are resolved. Ukrainian legislation, scientific researches, actual judicial practices are analyzed, the thorough conclusions of both theoretical and practical value regarding the outlined question are drawn.

Key words: object, object of the civil relationship, object of the obligation relationship, work product, service.

Вступ. Стаття 177 ЦК України як різновид об’єктів цивільних правовідносин розглядає результати робіт та послуг. 3'ясування їх сутності дає можливість здійснити формування ефективного правового режиму регулювання відносин щодо вказаних об'єктів.

Постановка завдання. Метою статті $є$ дослідження сутності результату робіт та послуг як об'єктів цивільних правовідносин на засадах наукової обгрунтованості та практичної доцільності.

Результати дослідження. Стаття 177 ЦК України результат робіт розглядає як один iз різновидів об'єктів цивільних правовідносин, проте як положення цієї статті, так і інші положення ЦК України не розкривають його сутність.

Аналіз переліку об'єктів цивільних правовідносин (ст. 177 ЦК України) дає підстави стверджувати, що якщо результат робіт розглядати як категорію в широкому сенсі (результат

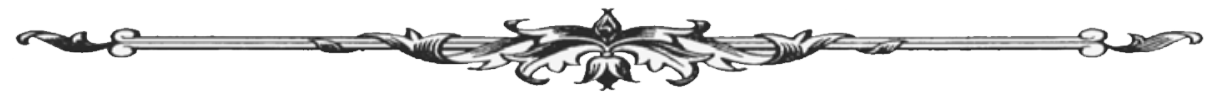


діяльності), то до результатів робіт можна віднести такі об'єкти, як речі (ті, що створені діяльністю людини), власне результат робіт, послуги, результати інтелектуальної, творчої діяльності тощо. Тоді постає логічне питання, як результат робіт відмежувати від всіх інших схожих об’єктів цивільних правовідносин за своєю сутністю? Варто відзначити що все, що в ЦК України передбачено як окремий самостійний об'єкт, за своєю сутністю є результатом робіт (діяльності), але результатом робіт як об'єктом цивільних правовідносин відповідно не $\epsilon$ і на нього не поширюється за загальним правилом режим іншого об'єкта, який схожий за своєю сутністю, але є іншим з точки зору його правового режиму.

За своєю суттю результат роботи являє собою результат певної діяльності особи. Будьяка діяльність особи, як така, може породжувати результат, який за своєю формою може бути як матеріальним, так і нематеріальним. Зокрема, О.О. Красавчиков відзначав, що діяльність може і не мати матеріального (упредметненого) результату, але вона не безрезультатна [1, с. 189]. В зв'язку з цим ми можемо припускати те, що в ст. 177 ЦК України результат робіт, що розглядається, може бути як матеріальний, так і нематеріальний.

Як результат, на практиці дуже часто як в учасників цивільних правовідносин, так i безпосередньо в суддів, які розглядають спори, що виникають 3 приводу розглядуваних об’ єктів (результатів робіт (діяльності) за своєю суттю), виникають питання щодо правильної кваліфікації відносин (який правовий режим застосовувати). Зокрема, складною є кваліфікація відносин щодо розмежування: 1) купівлі-продажу та підряду; 2) підряду та послуг; 3) підряду та створення за замовленням і використання об'єкта права інтелектуальної власності (ст. 1112 ЦК України). Не винятком з цього переліку є розмежування результату робіт як об'єкта цивільних правовідносин в межах регулювання одного договірного типу, оскільки відносини між собою схожі, але мають різний «правовий відтінок» - комплекс правових засобів, що формують особливий режим конкретної сфери правовідносин. Такий «відтінок» формується за рахунок особливостей конкретного результату робіт (матеріальний або інтелектуальний результат; в межах матеріального - результат щодо речей побутового вжитку або інших речей тощо), зокрема, в межах договору підряду (побутовий підряд, будівельний підряд або підряд на проведення проектних та пошукових робіт) або між договором підряду та договором на виконання науково-дослідних або дослідно-конструкторських та технологічних робіт тощо.

Так, між сторонами було укладено договір про створення за замовленням та використання програмного забезпечення, за яким виконавець зобов’язувався за завданням замовника створити програмний продукт “eWaybill” - електронний подорожній лист (програма), а також передати замовнику всі (в повному обсязі) виняткові майнові права на всі об’єкти права інтелектуальної власності, які будуть створені виконавцем під час виконання договору, а замовник зобов'язується прийняти належним чином виконані роботи, послуги та права, які передаються за договором. Вирішуючи питання щодо правової природи вказаного правочину та юридичної кваліфікації зобов'язань за ним, суд відзначив, що укладений правочин за своїм змістом та правовою природою є договором підряду, а не послуг, який підпадає під правове регулювання норм Глави 61 Розділу III Книги V ЦК України [2]. Як видно 3 указаного Рішення суду, суд проводив правову кваліфікацію відносин з приводу створення об'єкта права інтелектуальної власності (комп'ютерної програми) між договором підряду та договором про надання послуг, не підіймаючи навіть питання можливості його кваліфікації як договору про створення за замовлення і використання об'єкта права інтелектуальної власності (ст. 1112 ЦК України), предметом якого ч. 1 вказаної статті визначає «створення об’єкта права інтелектуальної власності відповідно до вимог другої сторони замовника». А тому, як видається, суд неправильно кваліфікував відносини, які за своєю суттю є договором про створення за замовленням і використання об’єкта права інтелектуальної власності, а не договором підряду, а тим більше договором про надання послуг. Такі помилки кваліфікації відносин, в яких об'єктом є результат робіт в широкому сенсі, не поодинокі. Саме договір створення на замовлення об'єкта права інтелектуальної власності схожий 3 підрядним договором, але істотною його відмінністю є творчий характер праці виконавця, внас-

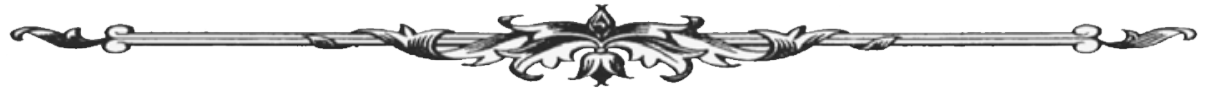


лідок чого з'являється не матеріальна річ, а такий об'єкт права, який регулюється Книгою IV ЦК України [3, с. 574]. Відповідно до Закону України «Про авторське право та суміжні права» комп'ютерна програма є різновидом електронної (цифрової) інформації, що знаходиться в електронній цифровій формі, придатній для зчитування і відтворення комп'ютером, що, відповідно, не дає підстави вести мову про відносини підрядного типу. Як відзначає О.С. Яворська, укладення договору про створення на замовлення і використання об'єкта права інтелектуальної власності спрямоване на створення відповідного об'єкта, що вирізняє його за правовою спрямованістю результату від решти договорів. Зазначений договір має зовнішню подібність 3 договорами підрядного типу, оскільки на його підставі створюється новий об'єкт. Але відмінною його ознакою від договорів підрядного типу є, власне, спрямованість на створення та використання саме об'єкта інтелектуальної власності, а не будьякого іншого. До правового регулювання відносин сторін підлягають застосуванню норми Глави 75 ЦК та Книги IV ЦК України, норми спеціального законодавства [4].

Зазвичай, коли йдеться про такий об'єкт цивільних правовідносин, як результат робіт, його завжди пов'язують з договором підряду. Проте ЦК України не дає чіткої відповіді, що об’єктом підряду є саме результат робіт. У положеннях Глави 61 ЦК України фігурують в одних випадках - «замовник зобов’язаний прийняти роботу» (ч. 1 ст. 837, 853 ЦК України), в інших випадках - «замовник зобов' язаний прийняти / передати / утримувати результат робіт». У такому разі, що ж передається - робота чи результат робіт як такий? Поняття роботи ЦК України не містить, але можна казати, що це є певний вид діяльності особи. Зокрема, Закон України «Про захист прав споживачів» визначає, що робота - це діяльність виконавця, результатом якої є виготовлення товару або зміна його властивостей за індивідуальним замовленням споживача для задоволення його особистих потреб (ст. 1). Якщо робота - це діяльність, то вона, відповідно, є невіддільною від особи і не може бути передана. Передаватися може сам результат робіт, який створюється в результаті такої діяльності (роботи). Тому правильним буде вести мову про передання за договором підряду не роботи, а результату роботи.

Яким цей результат повинен бути, положення про підряд ЦК України не вказує, а лише відзначається, що договір підряду може укладатися на виготовлення, обробку, переробку, ремонт речі або на виконання іншої роботи з переданням їі результату замовнику (ч. 2 ст. 837 ЦК України). 3 указаних положень слідує, що результат може проявлятися, по-перше, по відношенню до речі, по-друге, фразу «виконання іншої роботи з переданням результату замовникові» необхідно розцінювати як «інша робота по відношенню до речі», або взагалі інша робота, що не пов’язана з річчю, оскільки словосполучення «з переданням результату» викликає певну дискусійність.

Як вже відзначалося, результат роботи (діяльності) може бути як матеріальним, так і нематеріальним. Однак тут необхідно зробити деяке уточнення, оскільки певний різновид результату залежить не від діяльності або їі виду. Діяльність - це застосування своєї праці до чого-небудь [5, с. 228]. Це останнє «чого-небудь» може бути як матеріальним (річчю), так i нематеріальним, але знаходити своє об'єктивне вираження на матеріальному носії. Таким чином, стосовно чого змінюється діяльність людини в процесі виконання роботи, такий і буде результат роботи. Якщо діяльність спрямована на речі - результат є матеріальним, якщо діяльність не спрямована на речі (матеріальний об'єкт), відповідно, результат буде нематеріальним.

Цікавим в цьому аспекті є справа щодо виконання робіт з просіювання матеріалів. Так, між позивачем та відповідачем був укладений договір, за яким замовник доручає, а виконавець зобов'язується з власним просіювальним обладнанням та обслуговуючим персоналом на власний ризик та у передбачений договором строк виконати роботи з просіювання матеріалів (вказаних замовником) спеціально пристосованим для цього приладом, а замовник зобов' язується прийняти та оплатити роботи. Під час вирішення спору, який виник між сторонами, перед судом постало питання кваліфікації вказаних відносин. Суд відзначив, що вказані відносини не передбачають передання виконавцем замовнику уречевленого результату робіт з просіювання матеріалів [6]. Тобто результат, який створюється в результаті

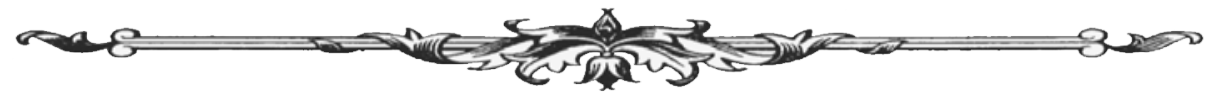


діяльності по просіюванню матеріалів, не має матеріальної (уречевленої) форми - тобто $\epsilon$ нематеріальним. Тому для кваліфікації матеріального результату робіт «приломлення» діяльності повинно бути не просто щодо речі, а має бути пов'язане з виготовленням або зміною властивостей такої речі.

Щодо кваліфікації результату як матеріального або нематеріального також має велике значення така обставина, як результат робіт, який створює річ, змінює її властивості, i результат, що втілюється в речі як матеріальному носії (об’єктивується). Для порівняння, наприклад, договір про надання науково-правового висновку, договір проведення пошукових робіт та договір надання аудиторських послуг (відповідно до Закону України «Про аудит фінансової звітності та аудиторську діяльність»). У такому разі цінність документа (звіт, висновок) складає не сам матеріальний носій (папір), а те, що міститься в документі і об'єктивується за його рахунок. Сторони, укладаючи договір, мають за мету отримати не сам документ як матеріальний носій, оскільки він є лише засобом передання блага, заради якого і укладається договір. Зокрема, п. 6 ч. 1 ст. 1 Закону України «Про аудит фінансової звітності та аудиторську діяльність» визначає, що аудиторський звіт - це документ, підготовлений суб'єктом аудиторської діяльності за результатами аудиту фінансової звітності (консолідованої фінансової звітності) відповідно до міжнародних стандартів аудиту та вимог цього Закону. Як бачимо, законодавець чітко відмежовує об’ єкт, на якому закріплюється результат діяльності, від самого результату діяльності. Правий у такому разі Р.С. Бевзенко, який зазначає, що в результаті діяльності виконавця за договором речі як самостійного блага, тобто блага, на виготовлення якого спрямовується результат діяльності виконавця, не виникає; інші матеріальні результати такої діяльності (наприклад, складання документів, нанесення фарби, установка обладнання тощо), хоча і можуть бути визнані речами, але все ж не можуть вважатися тими об'єктами, заради яких укладається договір; їх поява (виготовлення) має в певному сенсі випадковий характер [7, с. 351]. Тому результат діяльності, який знаходить своє об'єктивне вираження на певному матеріальному носії, не можна вважати матеріальним (уречевленим).

Якщо результат діяльності у формі результату робіт як об'єкта цивільних правовідносин (зокрема, договорів підрядного типу) є більш менш однозначним та не викликає заперечень, то розуміння послуги залишається дискусійним. Поняття послуги як об'єкта цивільних правовідносин чинний ЦК України не містить, є лише поняття договору про надання послуг (ст. 901). При цьому в науці цивільного права з приводу сутності послуги сформувалося дві найпоширеніші і в той же час протилежні точки зору: 1) послугою є безпосередньо сама діяльність виконавця послуги; 2) під послугою розуміють певний нематеріалізований результат, що створюється в результаті діяльності виконавця у вигляді корисного ефекту.

Якщо дивитися на послугу з боку виконавця, то можна казати, що послуга - це діяльність виконавця (перший підхід), якщо з боку замовника - корисний ефект (другий підхід). Як зазначає M.I. Брагінський, з позиції послугодавця відповідні дії являють собою «роботу», а для послугоотримувача - «послугу» [8, с. 229]. Але такий підхід до розуміння послуги не грунтується на теоретико-цивілістичних аргументах, а є більш спрощеним і не може бути покладений в основу побудови правової конструкції об' єкта-послуги. Слід відзначити, що під час розробки проекту ЦК України був обраний перший підхід - послугою є вчинення дії або здійснення певної діяльності [9, с. 109], проте вже у прийнятому ЦК України підхід був змінений на другу точку зору. Зокрема, у договорі про надання послуг (ст. 901 ЦК України) вказується: «...надати послугу, яка споживається в процесі вчинення певної дії або здійснення певної діяльності..». Як бачимо, послуга розглядається за межами поведінки (дій) особи і є тим, що створюється в процесі таких дій.

Безпосередньо судова практика на цей час випрацювала, виходячи 3 положень ст. 901 ЦК України, такі ознаки послуги як об'єкта цивільного правовідношення: 1) послуга не зводиться до самої дії або діяльності, а розглядається як окреме явище; 2) тісно пов'язана з особою виконавця та процесом вчинення ним дій, здійсненням діяльності; 3) має нематеріальний характер, а їі результат не набуває уречевленого вигляду $[2 ; 10 ; 11]$. Аналогічні ознаки послуги наводяться і в літературі [12, с. 397].

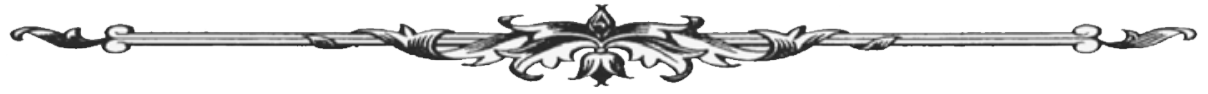


Таким чином, послуга як об'єкт формується у вигляді певного нематеріального блага як результату діяльності виконавця. Так, В.Ф. Яковлєв відзначав, що в договорі послуг об'єктом $€$ сама послуга як непередаване, нерозривно пов'язане з діяльністю послугодавця благо $[13$, с. 173]. Це нематеріальне благо розглядається у вигляді корисного ефекту, під яким слід розуміти «не що інше як сукупність корисних властивостей, які направлені на задоволення певної потреби людини» [14, с. 24]. Ціннісні властивості, споживча вартість послуги формуються не у діяльності виконавця, а в їі корисному ефекті.

Формування послуги як об'єкта цивільного правовідношення у вигляді корисного ефекту можливе лише в процесі теоретичної абстракції, на відміну від результату діяльності, що має уречевлений матеріальний характер, як це характерно для такого об'єкту, як результат робіт (договорів підрядного типу). Відсутність окремого результату послуги ще не означає відсутність позитивного економічного ефекту для їі споживача $[15$, с. 9]. Водночас, як відзначає С.С. Алексєєв, в реальних життєвих відносинах вид діяльності, що розглядається (діяльність виконавця послуги), та ії результат утворюють нероздільну єдність $[16$, c. 335]. Саме можливість теоретичного, абстрактного, а не фактичного відокремлення об'єкта-послуги (корисного ефекту) від діяльності виконавця послуги призводить до того, що прибічники підходу «послуги-дії» зводять послугу до дії та/або діяльності виконавця і не виділяють саме нематеріальне благо як те, заради чого сторона вступає у відносини 3 надання послуг. Зведення послуги до дії та/або діяльності виконавця послуги є безпідставним, науково-теоретично не обгрунтованим та не відповідає меті зобов'язальних правовідносин 3 надання послуг. 3 практичної точки зору цінність послуги для замовника складає безпосередньо ії корисний ефект, а не сама діяльність виконавця. 3 теоретичної точки зору зведення послуги до дій виконавця руйнує стадію реалізації в МПР та неможливість розмежування в структурі правовідношення його змісту (фактичної сторони) та об'єкту, оскільки вони в такому разі будуть співпадати.

Висновки. Отже, результат робіт та послуга як об’єкти цивільних правовідносин за своєю сутністю $є$ результатом діяльності особи, але є різними з точки зору форми вираження.

\section{Список використаних джерел:}

1. Советское гражданское право : в 2 т. / [Красавчиков О.А., Халфина Р.О., Кузнецова Л.Г. и др.] ; под общ. ред. О.А. Красавчикова. Москва : Высшая школа. Т. 1. 1968.

2. Рішення Господарського суду Дніпропетровської області від 06.04.2017 № 904/892/17. URL: http://www.reyestr.court.gov.ua/review/65812952.

3. Яркіна Н.С. Стаття 1112 Договір про створення за замовленням і використання об’єкта права інтелектуальної власності. Цивільний кодекс України: Науково-практичний коментар (пояснення, тлумачення, рекомендації з використанням позицій вищих судових інстанцій, Міністерства юстиції, науковців, фахівців). Т. 6: Право інтелектуальної власності / За ред. проф. І.В. Спасибо-Фатєєвої. Серія «Коментарі та аналітика». Харків : ФО-П Лисяк Л.С., 2011. С. 573-575.

4. Яворська О.С. Договори у сфері інтелектуального права: проблеми застосування чинного законодавства. URL: http://aphd.ua/publication-166.

5. Великий тлумачний словник сучасної української мови: 170000 слів / уклад. і голов. ред. В.Т. Бусел. Київ ; Ірпінь : ВТФ «Перун», 2004. 1440 с.

6. Рішення Господарського суду м. Києва. Справа № 910/9738/13 від 22.09.2014. URL: http://www.reyestr.court.gov.ua/Review/40641940.

7. Бевзенко Р.С. Гл. 37 Подряд. Практика применения Гражданского кодекса РФ частей второй и третьей / под общ. ред. В. А. Белова. 2-е изд., перераб. и доп. Москва : Издательство Юрайт ; Юрайт-Издат, 2011. 1525 с.

8. Брагинский М.И. Договор подряда и подобные ему договоры. Москва, 1999.

9. Сибільов М.М. Загальні положення регулювання відносин у сфері надання послуг за проектом нового Цивільного кодексу України. Вісник Академії правових наук України. № 7. 1996. С. 108-112.

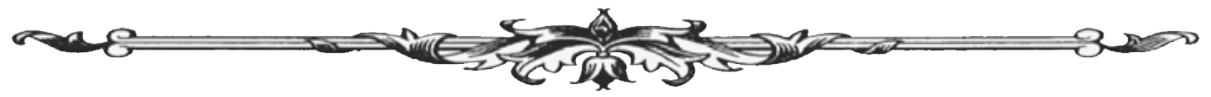


10.Рішення Господарського суду міста Києва від 13.04.2017 № 910/1092/17. URL: http://www.reyestr.court.gov.ua/Review/67096996.

11. Рішення господарського суду м. Києва від 02.03.2017 № 910/18789/16. URL: http://www.reyestr.court.gov.ua/Review/65382213.

12.Жилінкова I.В. Договір про надання послуг (Глава 45). Цивільне право : підручник : у 2 т. / В. І. Борисова (кер. авт. кол.), Л.М. Баранова, Т.І. Бєгова та ін.; за ред.. В.І. Борисової, І.В. Спасибо-Фатєєвої, В.Л. Яроцького. Харків : Право. 2011. Т. 2. 816 с.

13. Яковлев В.Ф. Договор подряда - гл. 34. Советское гражданское право. Под ред. О.А. Красавчиков. В 2-х томах. Том 2. Москва : «Высшая школа». 1968. 520 с. $160 \mathrm{c}$.

14. Агабабьян Э.М. Экономический анализ сферы услуг. Москва : Экономика, 1968.

15.Ким Е.В. (Елена Викторовна). Вопросы общего учения об обязательствах по оказанию услуг : автореферат на соискание ученой степени кандидата юридических наук. Специальность 12.00.03 Гражданское право; Предпринимательское право ; Семейное право ; Международное частное право / Е.В. Ким ; Науч. рук. Н.Д. Егоров ; Санкт-Петербургский государственный университет. Санкт-Петербург, 2007. 26 с.

16.Алексеев С.С. Проблемы теории права. Курс лекций в двух томах, Т. 1. Свердловск, 1972. 395 с.

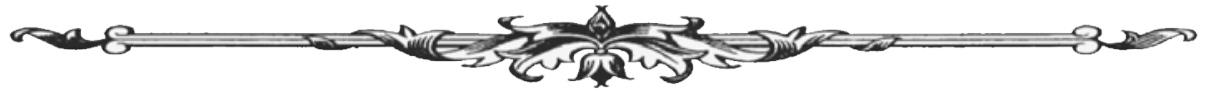

